\title{
WATER QUALITY ASSESSMENT USING DAPHNIA: A BRIEF REVIEW
}

\author{
Clara Rodrigues Pereiraa , Lílian Lefol Nani Guarieiroab \\ a, abSenai Cimatec, Brazil.
}

\begin{abstract}
Due to the need to discover methods that can measure the toxicity level of fresh and marine water quality, this study aimed to present a systematic review of the literature, indicating the culture conditions and toxicological tests used for different Daphnia species in the evaluation of water quality. Thus, the applied methodology was a systematic review that identified studies that addressed the application of Daphnia in the assessment of water quality. The results obtained from this research consisted of a compilation of articles, which presented the parameters that are most analyzed in Daphnia species, such as mobility and mortality, which can change when exposed to different chemical substances.
\end{abstract}

Keywords: Daphnia; water quality; toxicity.

\section{AVALIAÇÃO DA QUALIDADE DA ÁGUA UTILIZANDO A DAPHNIA: UMA BREVE REVISÃO}

Resumo: Devido a necessidade de descobrir métodos que possam mensurar o nível de toxicidade da qualidade de água doce e marinha, este estudo teve como objetivo apresentar uma revisão sistemática da literatura, indicando as condições de cultura e os testes toxicológicos utilizados para diferentes espécies de Daphnia na avaliação da qualidade de águas. Desta forma, a metodologia aplicada foi uma revisão sistemática que identificou estudos que abordassem a aplicação da Daphnia na avaliação da qualidade da água. Os resultados obtidos desta pesquisa consistiram em um compilado de artigos, que apresentaram os parâmetros que são mais analisados nas espécies de Daphnia, como mobilidade e mortalidade, os quais podem sofrer alterações ao serem expostos a diferentes substâncias químicas.

Palavras-chave: Daphnia; qualidade da água; toxicidade. 


\section{INTRODUCTION}

Unfortunately, the environment has been suffering the consequences of the impact of anthropogenic activities over the years, especially the aquatic environment, where numerous chemical compounds are found in it, which in addition to promoting ocean contamination, leaves this environment toxic and harmful to beings that live in it [1]. Therefore, research has been developed in search of methods that can measure the toxicology of these compounds on water quality, and their impact on the aquatic ecosystem, especially, due the lack of analytical tests that can make such information viable [2].

In this scenario of pollution in the oceans, there are aquatic beings that present in their bodies, a sensitivity to the chemicals that are dumped into the water, in a way that it is possible to detect the level of toxicology of these compounds and how they can affect these beings $[2,3]$. These organisms are micro crustaceans belonging to zooplankton species, that can be called of Daphnia, which are considered the oldest models, used in bioassays aimed the toxicology of water quality [4]. This is associated with their behavioral and physiological characteristics which respond in the presence of environmental bioindicators or chemical compounds [3].

Daphnia are micro crustaceans belonging to the Cladocera order which have species that can be found both in the sea and in fresh water, in the way that, due to their high sensitivity to different compounds, they are widely applied in ecotoxicological tests [5]. Thus, the species that are most used for toxicological tests are Daphnia Magna, Daphnia Smilis and Daphnia Pulex, which are usually found in fresh water, besides being easily cultivated in laboratories, for have response when in contact with different chemical compounds [5,6].

However, although Daphnia species are similar to each other, they have a different level of sensitivity, in a way that, one species may be more sensitive to a certain compound than another [6]. So, in this point, toxicological studies are developed to compare the impact of contaminants in more than one species of Daphnia [6]. Therefore, the most observed effect in toxicological tests, is the mobility of organisms exposed to chemical substances soluble or dispersed in water [7].

In this context, it is necessary to emphasize that the toxicity tests involving Daphnia follow criteria for carrying out the tests of these species, since, according to the CONAMA № 430 DE 13/05/2011 resolution, the ecotoxicological tests realized in effluent must use aquatic organisms of at least two different trophic levels [8]. Thus, for the manipulation of Daphnia in the laboratory, one of the most used guidelines is the OECD Guidelines for the Testing of Chemicals, whose main objective is to guide the best way in the acute toxicity tests of Daphnia, providing the necessary information for the cultivation of these beings (culture medium, solutions, test medium, etc), in addition to the ideal time of exposure of the organism to the analyzed substance [9]. In the case of the OECD, the two standards used are OECD 211, which is specifically aimed at Daphnia Magna and the OECD 202, that can be used for different species of Daphnia [9, 10].

Although standards are essential to contribute to effective analyzes in the use of Daphnia in the laboratory, it is necessary that the country where the study is performed, has this type of guideline, to ensure that the tests are in the appropriate conditions for analysis [6]. Thus, NBR12713, established by the Brazilian Association 
of Technical Standards (ABNT) has as its main guideline, specifying a method for evaluating the acute toxicity of liquid samples and water-soluble or dispersed chemical substances, using the species of Daphnia similis and Daphnia magna [ 7].

Therefore, this article aims to present a systematic review of literature, indicating the culture conditions and toxicological tests used for analysis of different Daphnia species.

\section{METHODOLOGY}

The methodology of this article consisted of a systematic review of the literature, focused on studies of the application of Daphnia in toxicological tests for the assessment of water quality. The flow of this systematic review is described in Figure 1.

Figure 1. Systematic review flow
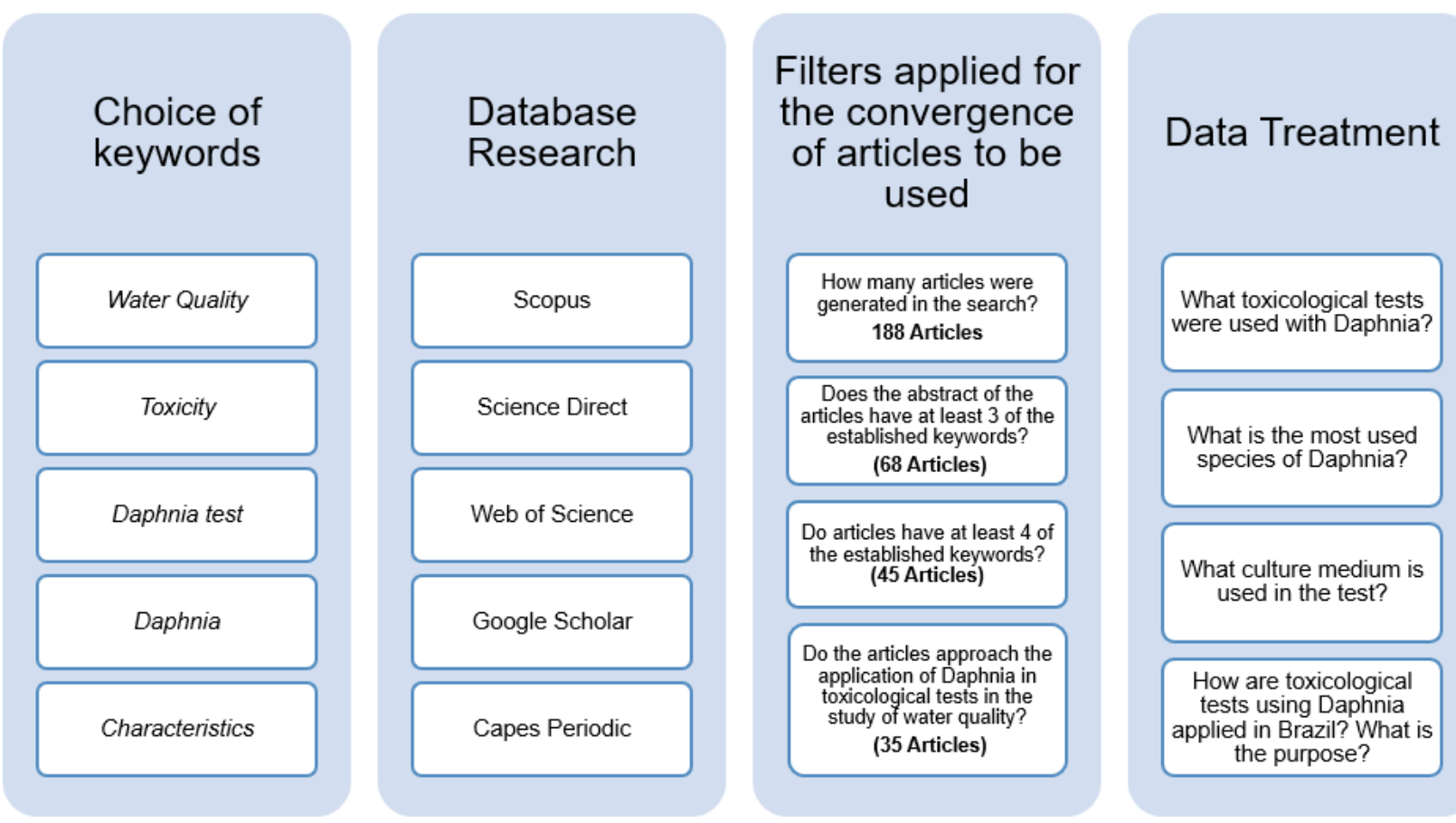

As previously presented, the systematic review of this study was performed in the following steps:

i) Choice of keywords with Boolean operators (and, or): "water quality", "toxicity", "daphnia test", "daphnia", "characteristics".

ii) Use of databases: Scopus (www.scopus.com), science direct (www.sciencedirect.com), capes (www-periodicos-capes-govbr.ez68.periodicos.capes.gov.br), web of science (www. webofknowledge.com) and google of scholar (https://scholar.google.com.br).

iii) Search period: 2011 to 2021 . 
iv) Application of filters, aimed to synthesize the articles found during the search.

It is worth to mention, that the use of Boolean operators (and, or) was important for a more refined result of articles that approached studies of Daphnia in toxicological tests, in addition to the use of filters, that served as a facilitator for the convergence of articles that attend the purpose of this study. However, although this method has allowed the acquisition of valid articles for this study, it is necessary to remember that in the current pandemic scenario, the remote access to these databases was not so simple, in a way that, the path used for the access of the databases mentioned previously, was through Google Scholar and Cape's Periodic.

\section{RESULTS AND DISCUSSION}

From the systematic review, it was possible to compile some articles, comparing the toxicological tests with the use of Daphnia, the most used Daphnia species, the culture medium used, and the toxicological parameters analyzed (Table 1). It is noteworthy that to explain the results of this study, it wasn't possible to present all the articles found, since the number of them is too high for this information space. Thus, six articles are presented that correlate the methods and standards used for it.

Table 1. Comparison of toxicological studies using Daphnia species

\begin{tabular}{|c|c|c|c|c|c|c|}
\hline Article Title & Country & $\begin{array}{c}\text { Evaluation } \\
\text { Site }\end{array}$ & Year & Article Purpose & $\begin{array}{c}\text { Tested } \\
\text { Daphnia }\end{array}$ & Toxicity Test \\
\hline $\begin{array}{c}\text { Advancements in effect- } \\
\text { based surface water quality } \\
\text { assessment [1] }\end{array}$ & Netherlands & $\begin{array}{l}\text { Laboratory of } \\
\text { the University } \\
\text { of Amsterdam }\end{array}$ & 2020 & $\begin{array}{c}\text { Evaluate the water } \\
\text { quality and get } \\
\text { analytical answers } \\
\text { about specific sources } \\
\text { of contamination }\end{array}$ & $\begin{array}{l}\text { Daphnia } \\
\text { Magna }\end{array}$ & $\begin{array}{l}\text { Bioassays performed on } \\
\text { dilution series of extracts } \\
\text { from all three passive } \\
\text { samplers, resulting in nine } \\
\text { in vivo responses which } \\
\text { was immobilized for } 48 \\
\text { hours of exposure }\end{array}$ \\
\hline $\begin{array}{c}\text { Assessing Domestic } \\
\text { Wastewater Effluent with a } \\
\text { Battery } \\
\text { of Bioassays after } \\
\text { Treatment with a Specific } \\
\text { Consortium } \\
\text { of Microalgae and Different } \\
\text { Flocculation Methods [11] }\end{array}$ & South Africa & $\begin{array}{l}\text { University of } \\
\text { Stellenbosch }\end{array}$ & 2020 & $\begin{array}{l}\text { To determine the } \\
\text { toxicity of supernatants } \\
\text { resulting from alum } \\
\text { coagulation and } \\
\text { chitosan flocculation of } \\
\text { algae biomass from } \\
\text { wastewater effluent } \\
\text { using the bioindicator } \\
\text { species }\end{array}$ & $\begin{array}{c}\text { Daphnia } \\
\text { Magna }\end{array}$ & $\begin{array}{l}\text { Five newborns of similar } \\
\text { size were selected for each } \\
\text { tray compartment. A series } \\
\text { of five samples were } \\
\text { selected for each solution } \\
\text { tested. Mortality was } \\
\text { defined as a lack of } \\
\text { movement after a gentle } \\
\text { nudge after } 24 \text { and } 48 \mathrm{~h}\end{array}$ \\
\hline $\begin{array}{c}\text { Toxicity of lead and } \\
\text { mancozeb differs in two } \\
\text { monophyletic Daphnia } \\
\text { species [6] }\end{array}$ & $\begin{array}{c}\text { Brazil and } \\
\text { Portugal }\end{array}$ & $\begin{array}{l}\text { Department of } \\
\text { Biology \& } \\
\text { CESAM, } \\
\text { University of } \\
\text { Aveiro, 3810- } \\
\text { 193, Portugal }\end{array}$ & 2019 & $\begin{array}{c}\text { To compare the } \\
\text { sensitivity of two } \\
\text { monophyletic Daphnia } \\
\text { from different climatic } \\
\text { areas to two different } \\
\text { contaminants } \\
\text { (inorganic and organic) } \\
\text { to induce negative } \\
\text { effects on the } \\
\text { ecosystem }\end{array}$ & $\begin{array}{l}\text { Daphnia } \\
\text { Magna and } \\
\text { Daphnia } \\
\text { Similis }\end{array}$ & $\begin{array}{l}\text { Newborns of both species } \\
\text { between } 6 \text { and } 24 \mathrm{~h} \text { were } \\
\text { exposed to a range of } \\
\text { chemical concentrations for } \\
21 \text { days. For each species, } \\
\text { the concentration range } \\
\text { was based on its sensitivity } \\
\text { to the test chemicals as } \\
\text { well as the results of acute } \\
\text { toxicity tests }\end{array}$ \\
\hline
\end{tabular}


Table 1. Comparison of toxicological studies using Daphnia species - Continuation

\begin{tabular}{|c|c|c|c|c|c|c|}
\hline Article Title & Country & $\begin{array}{c}\text { Evaluation } \\
\text { Site }\end{array}$ & Year & Article Purpose & $\begin{array}{l}\text { Tested } \\
\text { Daphnia }\end{array}$ & Toxicity Test \\
\hline $\begin{array}{c}\text { Saxitoxin-producing } \\
\text { Raphidiopsis raciborskii } \\
\text { (cyanobacteria) inhibits } \\
\text { swimming and } \\
\text { physiological parameters } \\
\text { in Daphnia similis [12] }\end{array}$ & Brazil & $\begin{array}{c}\text { Laboratory of } \\
\text { Evaluation } \\
\text { and } \\
\text { Promotion of } \\
\text { Environmental } \\
\text { Health, } \\
\text { Instituto } \\
\text { Oswaldo Cruz, } \\
\text { FIOCRUZ }\end{array}$ & 2019 & $\begin{array}{l}\text { To test the effects of } \\
\text { a neurotoxic strain of } \\
\text { cyanobacterium } \\
\text { Raphidiopsis } \\
\text { raciborskii (CYRF-01) } \\
\text { on swimming, activity } \\
\text { and physiological } \\
\text { parameters of } \\
\text { Daphnia similis }\end{array}$ & $\begin{array}{l}\text { Daphnia } \\
\text { Similis }\end{array}$ & $\begin{array}{l}\text { Acute tests were } \\
\text { performed to detect the } \\
\text { immobilization of } D \text {. } \\
\text { similis during an } \\
\text { exposure period of } 48 \mathrm{~h} \text {. } \\
\text { The number of dead and } \\
\text { immobilized individuals } \\
\text { were counted after } 30 \\
\text { min, } 1,2,24 \text { and } 48 \mathrm{~h} \\
\text { after exposure }\end{array}$ \\
\hline $\begin{array}{c}\text { Protein profiling as early } \\
\text { detection biomarkers for } \\
\text { TiO2 nanoparticle toxicity } \\
\text { in Daphnia magna [13] }\end{array}$ & Portugal & $\begin{array}{c}\text { Nova Lisboa } \\
\text { University }\end{array}$ & 2018 & $\begin{array}{l}\text { Evaluate the toxicity } \\
\text { and effects of } \\
\text { Daphnia magna } \\
\text { exposed to } \mathrm{TiO}_{2}-\mathrm{NPs} \text {, } \\
\text { through the response } \\
\text { of the protein profile }\end{array}$ & $\begin{array}{c}\text { Daphnia } \\
\text { Magna }\end{array}$ & $\begin{array}{l}\text { The acute toxicity of } \mathrm{TiO}_{2} \\
\text { NPs in Daphnia Magna } \\
\text { was evaluated according } \\
\text { to ISO } 6341 \text {, in which the } \\
\text { inhibition of mobility of } \\
\text { juveniles D.Magna, aged } \\
\text { between } 6-24 \mathrm{~h} \text { and } \\
\text { exposed in } 48 \mathrm{~h}\end{array}$ \\
\hline $\begin{array}{c}\text { The acute toxicity of } \\
\text { thallium to freshwater } \\
\text { organisms: Implications } \\
\text { for } \\
\text { risk assessment [14] }\end{array}$ & $\begin{array}{c}\text { United } \\
\text { Kingdom }\end{array}$ & $\begin{array}{l}\text { University of } \\
\text { Plymouth }\end{array}$ & 2015 & $\begin{array}{l}\text { To assess the acute } \\
\text { toxicity of TI(I) to } \\
\text { three key trophic } \\
\text { species according to } \\
\text { standardized OECD } \\
\text { methods }\end{array}$ & $\begin{array}{c}\text { Daphnia } \\
\text { Magna and } \\
\text { Daphnia Pulex }\end{array}$ & $\begin{array}{l}\text { Newborns were exposed } \\
\text { in triplicate (with } 30 \\
\text { animals per treatment) } \\
\text { and for } 48 \mathrm{~h} \text { to } \mathrm{TI}(\mathrm{I}) \\
\text { concentrations ranging } \\
\text { from } 60 \text { to } 1200 \mu \mathrm{I} \mathrm{I}^{-1}\end{array}$ \\
\hline
\end{tabular}

From the comparative analysis presented in table 1, it was possible to detect that most of the explained articles used the Daphnia Magna species for toxicological bioassays. This data is linked to the fact that $D$. Magna is widely used as a bioindicator for the analysis of water quality, since it has a short doubling time and high sensitivity [11]. However, Daphnia Similis also has a significant level of importance when referred to ecotoxicological assessments, for being broadly distributed in the world, as in Europe, North America, and South America [6, 12]. In Brazil, it is frequently used for tests and considered a standard species, due to its accessibility in temporary, shallow, and turbid lakes [12].

The toxicological tests, in all the studies presented, used the mobility of organisms as an essential parameter for analysis. The immobilization test of these beings indicated for how long of exposure to the analyzed compound, these organisms tend to lose their mobility $[12,14]$. It was analyzed how long these beings exposed to chemical substances survive and what is the necessary age of Daphnia to be used for acute toxicity tests $[112,13,14]$. In addition, some articles approached the study of Daphnia species compared to other trophic levels, such as algae and zebrafish, in order to measure the sensitivity of these organisms in the presence of thallium and it can be observed that Daphnia species are less sensitive than the microalgae analyzed [14]. 
Due to the use of different species in the articles presented, a table was made with the studied Daphnia species, indicating its applicability in toxicological tests and the parameters analyzed for these organisms (Table 2).

Table 2. Comparison of applicability of different Daphnia species

\begin{tabular}{|c|c|c|}
\hline Daphnia Species & Application in toxicity & Parameter Analyzed \\
\hline Daphnia Magna $[1,6,11,13,14]$ & $\begin{array}{l}\text { Metal Exposure [1] } \\
\text { Exposure to metal lead( }(\mathrm{Pb}) \text { and the fungicide } \\
\text { mancozeb [6] }\end{array}$ & $\begin{array}{l}\text { Mortality }[1,11,13,14] \\
\text { Immobilization }[6,11] \\
\text { Reproduction }[6,13]\end{array}$ \\
\hline Daphnia Similis $[6,12]$ & $\begin{array}{l}\text { Exposure to metal lead }(\mathrm{Pb}) \text { and the fungicide } \\
\text { mancozeb [6] } \\
\text { Exposure to effects of a neurotoxic strain of } \\
\text { cyanobacterium Raphidiopsis raciborskii [12] }\end{array}$ & $\begin{array}{l}\text { Immobilization [6] } \\
\begin{array}{c}\text { Antennae movements, thoracic limbs, post- } \\
\text { abdominal claw and heart rate [12] }\end{array}\end{array}$ \\
\hline Daphnia Pulex [14] & Exposure to TI [14] & $\begin{array}{c}\text { Mortality [14] } \\
\text { Immobilization [14] }\end{array}$ \\
\hline
\end{tabular}

It is necessary to point out that these indicators are associated with the physiological system of Daphnia, such as mortality, which is associated with feeding activities determined by filtration and ingestion rates (Figure 1). The filtration rate consists of the volume of medium released per unit of time, in which the filtration process takes place in the thoracic limbs (the activity of the thoracic limbs is measured by calculating their beats per unit of time), generating a stream of water throughout the which food particles are directed to the mouth for ingestion [15]. The ingestion rate corresponds to the number of cells consumed by Daphnia in a specific period of time. It is noteworthy that these two rates can be quantified by measuring the decrease in particle concentration in water over time and by analyzing the material accumulated in the viscera [15].

In this context, the indicators of toxicity to chemical substances were analyzed (Table 2), for different species of Daphnia (Magna, Similis and Pulex). It was observed that all articles analyzed the same parameters, however, mortality was one of the most analyzed indicators, showing a degree of sensitivity of species to exposure of these compounds: Daphnia Pulex > Daphnia Similis > Daphnia Magna. These parameters were expressed in different ways in the studies, where the lethal concentration (LC) indicates the value range of a certain compound that can cause the death of Daphnia, as well as the effect concentration (EC), that indicates the responses that a determinate compound can induce in these organisms after a time of exposure. 
Figure 1. Daphnia Feeding Activity

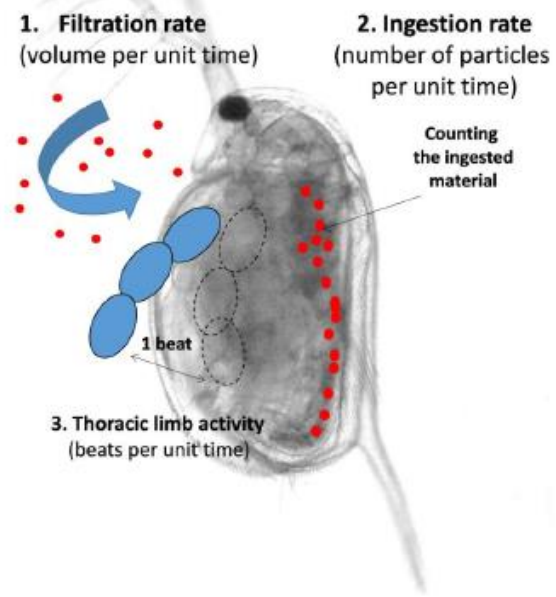

Source: BOWNIK, 2020 [14].

It was also identified that among the compounds analyzed in the studies, Daphnia species are more sensitive to metals. For example, in the study that addresses the exposure of Daphnia to lead (Pb), it showed that Daphnia Magna tends to decrease in size compared to Daphnia Similis [6]. Each Daphnia species reacts in a different way to a certain chemical compound, to the detriment of that, it is necessary that more studies are developed, to mitigate the toxicity of different compounds found in the aquatic environment.

\section{CONCLUSION}

Through the systematic review applied to this study, it was possible to generate a compilation of articles, which provided significant data for the use of the Daphnia species in the assessment of water quality toxicity, from the type of Daphnia to be used, to the ideal medium of culture and parameters to be analyzed.

Therefore, from these studies, it was possible to detect that the species of Daphnia Magna and Daphnia Similis are the most used bioindicators in toxicological tests. This happens since they have a high sensitivity to chemical substances and a physiology that allows analyzing the behavior of compounds in these beings. Also, it was possible to identify parameters (mortality, mobility, reproduction) in Daphnia that can change in the presence of chemical substances, such as mobility and mortality of these beings, that can indicate the level of toxicity of these chemical compounds.

\section{REFERENCES}

${ }^{1}$ DE BAAT, M. L. et al. Advancements in effect-based surface water quality assessment. Water research, v. 183, p. 116017, 2020.

2ZAGREBIN, A. O.; RUMYANTSEV, V. A.; TONKOPII, V. D. Developing methods for bioidentification of xenobiotics for water quality assessment. Water Resources, v. 43, n. 1, p. 141-144, 2016. 
${ }^{3}$ TKACZYK, Angelika et al. Daphnia magna model in the toxicity assessment of pharmaceuticals: A review. Science of The Total Environment, p. 143038, 2020.

${ }^{4} E N A C H E$, loana et al. Diversity and distribution of Daphnia across space and time in Danube Delta lakes explained by food quality and abundance. Hydrobiologia, v. 842, n. 1, p. 39-54, 2019.

${ }^{5}$ GOSSET, Antoine; FERRO, Yannis; DURRIEU, Claude. Methods for evaluating the pollution impact of urban wet weather discharges on biocenosis: a review. Water research, v. 89, p. 330-354, 2016.

${ }^{6}$ ARAUJO, G. S. et al. Toxicity of lead and mancozeb differs in two monophyletic Daphnia species. Ecotoxicology and environmental safety, v. 178, p. 230-238, 2019.

${ }^{7}$ NBR 12713. Aquatic Ecotoxicology - Acute Toxicity - Bioassay Methodology with Daphnia Spp (Crustacea, Cladocera). Brazilian Association of Technique Standards. ABNT, 2016.

'LEGISWEB. RESOLUÇÃO CONAMA № 430 DE 13/05/2011, 2011. Available at: $<$ https://www.legisweb.com.br/legislacao/?id=114770>

${ }^{9}$ OECD. Guideline 211: Daphnia magna reproduction test. OECD Guidel. Test. Chem. Section 2, 23. OECD, 2012.

${ }^{10}$ OECD. Guideline 202: Daphnia sp., acute immobilisation test. OECD Guidel. Test. Chem. 1-12. OECD, 2004.

${ }^{11}$ VAN DEN BERG, M. F. et al. Assessing Domestic Wastewater Effluent with a Battery of Bioassays after Treatment with a Specific Consortium of Microalgae and Different Flocculation Methods. Water, Air, \& Soil Pollution, v. 231, p. 1-15, 2020.

${ }^{12}$ FERRÃO-FILHO, Aloysio da S.; DA SILVA, Diego Amparo C. Saxitoxin-producing Raphidiopsis raciborskii (cyanobacteria) inhibits swimming and physiological parameters in Daphnia similis. Science of the Total Environment, v. 706, p. 135751, 2020.

${ }^{13}$ SÁ-PEREIRA, Paula et al. Protein profiling as early detection biomarkers for TiO 2 nanoparticle toxicity in Daphnia magna. Ecotoxicology, v. 27, n. 4, p. 430-439, 2018.

${ }^{14}$ TATSI, Kristi et al. The acute toxicity of thallium to freshwater organisms: implications for risk assessment. Science of the Total Environment, v. 536, p. 382-390, 2015.

${ }^{15}$ BOWNIK, Adam. Physiological endpoints in daphnid acute toxicity tests. Science of the Total Environment, v. 700, p. 134400, 2020. 